nLnVhfGRvfGd4OjU0Nzg0OTc5ZmU3OWJ1YzA $\quad$ [in Ukrainian].

Adamova, I. Z., Holovachuk, T. I. (2012). Dystantsiine navchannia: suchasnyi pohliad na perevahy ta problemy [Distance learning: a modern look at the benefits and challenges]. Visnyk Chernivetskoho torhovelno-ekonomichnoho instytutu. Vytoky pedahohichnoi maisternosti Bulletin of the Chernivtsi Trade and Economic Institute. The origins of pedagogical skills, 10, 3-6 [in Ukrainian].

Kukharenko, V.M. (2018). Pereshkody vprovadzhenniu dystantsiinoho navchannia [Obstacles to the introduction of distance learning]. Proceedings from Distance education: realities and prospects '18: I Vseukrainska naukovo-praktychna konferentsiia (12 hrudnia 2018 r.) The first all-Ukrainian scientific-practical conference (pp. 35-38). Kharkiv: KhNPUim. H. S. Skovorody [in Ukrainian].

Mukoviz, O. P. (2016). Osnovy orhanizatsii dystantsiinoho navchannia u systemi neperervnoi osvity [Fundamentals of distance learning in the system of continuing education]. Uman: FOP Zhovtyi O. O. [in Ukrainian].

Radkevych, V. O. (2020). Suchasni tendentsii rozvytku profesiinoi osvity [Current trends in vocational education]. Proceedings from Current issues of technological and vocational education '20: Mizhnarodna naukovopraktychna konferentsiia (14 travnia 2020 r.) - International scientific-practical conference (pp. 60-66). Hlukhiv: Hlukhivskyi NPU im. O. Dovzhenka [in Ukrainian].

Ніколаснко О. О.

доктор історичних наук, дочент, професор кафедри історії Украӥни Харківського національного педагогічного університету імені Г. С. Сковороди https://orcid.org/0000-0002-2294-4198

\title{
КУЛЬТУРНО-ОСВІТНЯ ДІЯЛЬНІСТЬ ПОЛЬСЬКИХ ЖІНОК У МІСТАХ РОСІЙСЬКОЇ ІМПЕРІЇ НАПРИКІНЦІ ХІХ - НА ПОЧАТКУ ХХ СТ.
}

Польські жінки традииійно відігравали важливу роль у підтримиі духовної культури громади. Особливо відчутною була їх роль у великих містах імперії - Москві, Києві, Петербурзі та Одесі, де зосереджувалась значна кількість польського населення. Мета даної статті полягає у виявленні характерних рис участі жіноцтва в культурному житті полонії міст. Для иььго використані методи індукиї, аналізу, історико-типологічний метод. На підставі аналізу архівних джерел та досліджень з даної тематики встановлені форми участі жінок в системі освіти польського населення, філантропічній діяльності, підтримиі начіональної культури - у розвитку театрального і музичного життя, розповсюдженні бібліотек тощо. Виявлено, що у всіх названих галузях жінки виявляли свої творчі здібності, організуючі різноманітні освітні заклади, громадські організаиії, мистецькі заходи.

Ключові слова: жінки, поляки, міста, Російська імперія.

Polish women have traditionally played an important role in supporting the spiritual culture of the community. Their role in the major cities of the empire - Moscow, Kiev, St. Petersburg and Odessa, where a large number of Polish population was concentrated - was especially significant. The purpose of this article is to identify the characteristics of women's participation in the cultural life of cities. For this purpose, methods of induction, comparative analysis, historical and typological method are used. On the basis of the analysis of archival sources and studies of this topic, the forms of women's participation in the polish population's education system, philanthropic activities, support of national culture - in the development of theatrical and musical life, distribution of libraries, etc. have been established. It was revealed that in all these areas women showed their creativity by organizing various educational institutions, social organizations and cultural events.

Keywords: women, Poles, cities, Russian Empire.

Важливу роль у житті польського населення міст Російської імперії відігравала культура. Духовна спадщина польського народу стала чинником інтеграції тих, хто жив далеко від батьківщини. В кінці XIX ст. у багатьох російських містах виникли організації, що підтримували національний театр, поширювали літературу, пропагували польську музику. Ці товариства дозволяли зберегти почуття національної єдності, згуртовуючи співвітчизників.

Величезне значення в підтримці національної культури належало польським жінкам. Однак їх імена не часто можна зустріти серед засновників або керівників культурних організацій, тому важко встано- 
вити їх роль в організації культурного життя поляків. До того ж, громадське життя було сферою панування чоловіків, що спричиняє актуальність звернення до питання про роль жіноцтва у збереженні національної культури. Однак багато фрагментарних даних зі статутів, звітів, газетних повідомлень демонструють особливий внесок жінок в підтримку і поширення національної культури.

Історія польської діаспори в Російській імперії є популярною темою наукових студій польських, російських і українських дослідників. Однією 3 найперших праць 3 даної теми $є$ монографія польського історика 3. Лукавского «Ludność polska w Rosii: 1863-1914», присвячена загальній характеристиці польської діаспори в імперії, етапам та особливостям розселення поляків, їх соціальному складу, аналізу діяльності різноманітних національних організацій та партій [Lukawski Z. 1978]. Зараз виходить багато краєзнавчих досліджень, які розкривають особливості історії поляків різних регіонів, а також вносять в історію імена поляків, які допомагали зберігати національну самосвідомість [Поляки в России: 2007; Смирнова Т. М. 2013; Коженьовський М. 2015]. Однак імена жінок досі залишаються незаслужено забутими.

В даній розвідці буде проаналізовано участь польок у культурному житті своєї етнічної спільноти тих міст Російської імпеpiï, де проживала значна кількість польського населення, а саме Петербурга, Москви, Києва і Одеси. Наукова новизна дослідження полягає в порівняльному аналізі діяльності полонії визначених великих поліетнічних міст, де жінки виявляли різноманітні громадські ініціативи й реалізовували творчий потенціал.

Щоб оцінити діяльність польських жінок в культурному житті міст Російської імперії, звернемося до різних джерел. Матеріали Першої перепису населення, проведеного в імперії у 1897 р., дозволяють виявити кількість польських жінок у найбільш великих містах, рівень їх освіти і особливості зайнятості.

Матеріали архівів, які містять звіти про роботу польських організацій, дозволяють оцінити внесок жінок в їх діяльність.
Польське населення проживало в багатьох великих містах Російської імперії. Найбільша кількість населення, що визнала польську мову рідною (а саме таке формулювання було поставлено в переписі і використовується сьогодні для визначення національної ідентичності - О. Н.) проживало в столиці імперії - Санкт-Петербурзі - 36729 осіб, серед них жінок -13 917. Наступним за чисельністю польського населення містом був Київ, в якому їх проживало 8571 чоловіків і 8008 жінок. В Одесі кількість поляків була 11388 чоловіків і 6007 жінок, а в Москві - 6267 і 2969 відповідно [Первая всеобщая перепись].

Диспропорція чоловічого і жіночого населення пояснюється тим фактом, що там, де вона разюча, були зосереджені військові гарнізони 3 польськими військовослужбовцями. Розрахунки польського дослідника 3. Лукавського показали, що за вирахуванням даної категорії населення, чисельність чоловіків i жінок частково зрівнюється [Lukawski Z. 1978: 84].

Слід зауважити, що Москва і Петербург були об'єктами польської міграції як центри імперії, в яких зосереджувалися навчальні та адміністративні установи, промислові підприємства. Тут відкривалися шанси знайти роботу, зробити кар'єру, змінити свій соціальний статус.

Київ і Одеса були населені поляками здавна. Київ, столиця південно-західного генерал-губернаторства, притягував польських жителів регіону. Одеса, що бурхливо розвивалася у XIX ст., поліетнічний центр, також як і Київ, була населена польськими вихідцями 3 правобережних українських губерній.

Рівень грамотності польок був високим. У Москві він становив 79, 4\% (2358 жінок), в Києві - 74, 9\% (6005), Петербурзі $68,5 \%$ (9563) та Одесі - 65, 8\%. Впадають в око дані про мову навчання. Більшість грамотних жінок були грамотні «по російськи». Таких налічувалося від 58, 4\% кількості грамотних жінок в Москві до 74, 9\% відповідно в Одесі. Грамотних же «іншою мовою», думається, що в нашому випадку це польська, так як їі визнали рідною респондентки, становила від $8,1 \%$ в Москві до 15 , $1 \%$ в Петербурзі. Такі цифри дозволяють 
судити про русифікаційні тенденції в галузі освіти.

Освіту «вище початкової» отримали 33, 5\% від всіх грамотних польських жінок Москви, 22,1\% Петербурга, 16, 4\% - Києва і $11,7 \%$ - Одеси. Дана характеристика є свідченням соціального складу польської спільноти міст. Якщо в Москві більшість серед поляків становили службовці, інтелігенція, то в Одесі їх відсоток був порівняно невисоким. Натомість у цьому місті значною була кількість робочих, ремісників, міських низів, які прагнули дати дівчаткам освіту, але не думали про ii якість або підвищення [Ніколаєнко О. 2012].

Доволі високим, у порівнянні з іншими етнічними групами, як от росіянки чи українки, був показник зайнятості польок у суспільному виробництві, що також можна встановити за переписом. Найвищий рівень зайнятості жінок був у Москві - 49,3\% (1456 жінок), а найнижчий - у Києві, 39\%. В Одесі та Петербурзі цей показник дорівнював 40, 3\% і 44\% відповідно.

Більшість жінок, зайнятих в суспільному виробництві, працювали служницями. Про це свідчать такі цифри: найменший показник дорівнював 23\% в Москві, найбільший в Одесі $-47,7 \%$. Багато жінок жили за рахунок доходів від майна і капіталу, а також за рахунок коштів, одержаних від різних установ - від 7 до 22\%. Близько 10\% жінок у всіх досліджуваних містах були зайняті виготовленням одягу.

Статистичні дані свідчать про строкатий соціальний склад польської діаспори у великих містах Російської імперії. Чисельність жіноцтва та його соціальний склад залежав від багатьох чинників, як то динаміка розвитку міста, його місце в системі державного управління, економічний потенціал $\mathrm{i}$ розвиток інфраструктури тощо. Високий відсоток освіченості польок, їх зайнятості слугували передумовою участі жінок в суспільному житті міст.

Традиційним напрямком громадської діяльності польських жінок в містах була участь у благодійництві. У $80-\mathrm{x}$ р XIX ст. благодійні організації при римсько-католицьких церквах виникли в Одесі (1882 г.), Петербурзі (1884 г.), Москві (1885г.). Їх засновниками стали відомі польські громадські діячі разом зі священиками.

У своїх статутах дані організації вважали своїми головними цілями допомогу одновірцям, сиротам, інвалідам, людям похилого віку, учнівській молоді та ін. Активну участь в роботі благодійних організацій брали чоловіки, хоча ця сфера вважалась традиційно жіночою. Швидше за все, жінки, хоч і не входили до складу Правлінь, проте робили конкретні кроки в благодійній роботі.

Одним 3 основних статей доходу благодійних товариств був Щорічний бал, який збирав не тільки польську громадськість, але заможних і відомих городян. До програми цього заходу входили концерт $з$ танцями, розіграшами, виступами іменитих гостей. Підготовка та організація балу, продаж квитків, влаштування виступів була заслугою, як правило, жінок [Kraj: 11].

Іншим важливим джерелом доходів благодійних товариств були кошти від проведених концертів і вистав. Тут також брали участь жінки, готуючи i прикрашаючи приміщення, розсилаючи запрошення. Молодь брала участь у виставах, показуючи «живі образи» - костюмовані сценки, для постановки яких використовувалися відомі твори польської літератури.

Жінки були не тільки учасницями благодійних товариств, а й об'єктом їхньої допомоги. При церквах відкривалися притулки для дівчаток сиріт, що діяли в Петербурзі, Москві, Одесі. Засновницями таких установ були активні члени благодійних товариств. У столиці імперії дружини членів благодійного товариства при парафії св. Катерини у 1900 р заснували власну організацію - Дамський гурток. У нього входили як вчительки, так і жінки, що фінансували проекти гуртка. Згодом Гурток став самостійною організацією, ініціювавши відкриття притулку і школи для дівчаток сиріт. Крім утримання притулку, Гурток приділяв увагу освіті вихованок, відкривши для них початкову школу, і піклуючись про переведення учениць в жіночі гімназії [Чаплицкий Б. 2009: 126-137].

Крім світських жінок, які брали участь у благодійній діяльності, важливе значення набували черниці таємних католицьких ор- 
денів. Так як жіночі католицькі монастирі зникли в імперії після розгрому Січневого повстання 1863-1864 pp., то з дозволу Ватикану тут постали таємні чернечі громади. Їх головною метою було духовне вдосконалення і допомога ближнім. Черницям для конспірації своєї діяльності не було потрібно носити спеціальний одяг. При таємних жіночих монастирях були засновані сиротинці, початкові школи, швацькі майстерні.

На півдні однією з яскравих представниць польського громадського руху була Марія Джевецька. Одна із засновниць Ордена Родини Mapiï (Rodziny Maryi), вона доклала багато зусиль, щоб відкрити в Одесі ще в 90-х pp. XIX ст. притулок для дівчаток, початкову школу [Ніколаєнко О. О. 2015].

У Петербурзі таку діяльність розгорнула Болеслава Лямент, засновниця ордена міссінерок Святого сімейства, яка відкрила спочатку притулок при парафії св. Казимиpa, а потім і приватну гімназію, в якій навчалося близько 400 дівчат [Чаплицкий Б. 2010: 142-157]. Засновницею чернечої організації урсулінок в столиці стала Юлія Марія Лендоховська, яка крім поширення католицької віри, сприяла ще й навчанню дівчат.

Благодійна діяльність польських городянок часто супроводжувалася культурнопросвітницькою діяльністю. Світські жінки поєднували організацію благодійних акцій 3 підтримкою національної культури. Для послушниць таємних жіночих релігійних орденів важливим напрямком діяльності було поширення освіти. Влаштування притулків для дітей католиків передбачало і заснування початкових шкіл, в яких діти навчалися рідною мовою.

Новий етап в житті польської спільноти імперії почався з революцією 1905-1907 pp., коли було дозволено створення національних культурних товариств. 31906 р по всій країні були організовані різноманітні польські культурно-просвітницькі організаціiі. Ђx можна класифікувати 3 напрямками діяльності: національно-культурні товариства, театрально-музичні організації, спортивні союзи.

Dom Polski (Будинок Польський) - загальна назва організацій, метою яких, як за- значалося у статутах, було «дати можливість членам зборів проводити час зі зручністю і користю», для чого були засновані гуртки музики, співу, драматичного мистецтва, гімнастичних вправ, влаштовувалися літературні вечори, публічні лекції, бібліотеки. Такі Будинки були створені в Одесі, Москві, Києві, Петербурзі, Харкові, Ризі та інших.

Першим був заснований Польський дім в Одесі у 1906 р з ініціативи А. Каленкевіча. Основною турботою засновників стало створення такої національнокультурної організації, що приєднала б до культурного життя і міські низи - робочих, ремісників і т.п. Організація складалася з 5 секцій - шкільної, бібліотечної, господарської, видовищ і забав, лекційної. Найактивніше працювала секція видовищ, так як молодь із задоволенням збиралася і влаштовувала аматорський театр, виступала 3 піснями, танцями. Також працювали бібліотечна і лекційна секції [ДАОО: 1-5].

Важливу функцію поширення й підтримки польської культури взяли «Ogniwa» або «Ogniska», засновані у 1906 р. у Києві, Одесі та Петербурзі. Вони влаштовували дружні вечори, постанови, лекції, засновували бібліотеки $з$ читальними залами. У своїй більшості ці товариства збирали польську міську інтелігенцію [Kalendarz: 183185].

Популяризацією польської культури займалося i Polskie towarzystwo milosnikow mystectw (Польське товариство прихильників витончених мистецтв) у Петербурзі. Воно складалося 3 чотирьох секцій: драматичної, музичної, літературної і художньої. Активною діячкою організації була Л. Чаплинська [Смирнова Т. М.: 143].

Незабаром у столиці 1908 р. було створено ще одне національно-культурне товариство «Promien» (Луч), що об'єднало численну колонію поляків робітничих околиць. I хоча дана організація була, скоріше, товариством взаємодопомоги, духовна підтримка співвітчизників теж входила до іiі завдань [Lukawski Z. 1978: 155]. Promien opганізовував концерти, музичні і танцювальні вечори, театральні вистави. Пізніше, у 1909 р., були організовані хор і оркестр. 
У цій організації, що об'єднувала міські низи, виникали революційні ідеї. Члени польських товариств, учасники революційних гуртків, популяризували свої ідеї на різноманітних зустрічах і вечорах.

Різноманітність польських культурних товариств в містах можна пояснити соціальною стратифікацією польської діаспори. Членські внески в цих організаціях були різними, що обумовлювало їх різний соціальний склад. На прикладі одеських організацій можна встановити, що щорічна плата в Польському Домі становила 2 крб. 40 коп. (в Петербурзі - 3 крб.), а в Ognisko - 10-15 крб [Горун 2003: 182].

Жінки брали активну участь в діяльності національно-культурних організацій, хоча їх імен немає серед засновників або членів правлінь. Вони ставали ініціаторами зустрічей, брали на себе турботу про костюми, облаштування приміщення, театральний репертуар тощо. У той же час затверджувати статути організацій або перейматись проблемами із пошуком приміщень жінкам було важче, так як їх досвід суспільного життя був обмежений.

Найбільш динамічним був розвиток театрального i музичного життя поляків. Польські театральні трупи гастролювали в багатьох великих містах імперії і мали успіх, а музиканти і співаки збирали численні зали на своїх концертах. Любов до театрального мистецтва виражалася і в створенні аматорських театральних колективів.

У 1906 р. в Одесі було створено товариство Lira (Лipa), метою якого було підтримка польської музики і створення національного театру в місті. I хоча на початку своєї діяльності організація не мала постійного приміщення, однак у рік свого створення показала 50, а 1907 р. 32 постанови [Kalendarz 1912: 183-185]. Не менш активно проходило театральне життя в інших містах. У Петербурзі існувало Artystyczne kolko dam, яке об'єднувало любителів театрального і музичного мистецтва і яке організовувало театральне життя поляків Петербурга. Серед найпопулярніших авторів п'єс можна назвати А. Фредро, М. Балуцького, С. Пшибильского.

Як показують дослідження, наприкінці XIX - на початку XX ст. відбувалося ста- новлення польського театру в російських містах - від аматорського до професійного. Театральні вистави польських п'єс, поставлені гроном аматорів на кошти, що відпускалися театральними товариствами, поступово перестали задовольняти публіку. Театральні колективи вимагали професійного керівництва, регулярних репетицій i приміщення для них [Горбатовський П. 2008; Коженьовський 2015: 446-454]. У Києві, де театральні вистави давали Товариство любителів театрального мистецтва, Огніско, Ліра, а також різноманітні запрошені трупи, виникли передумови для становлення польського професійного театру.

Польські жінки виступали не тільки на сцені, але були також і сценаристками, постановницями сцен, засновницями театральних колективів.

Найчастіше жінки виступали і засновницями бібліотек. При Одеському Польському домі бібліотекою керувала Є. О. Павловська, яка тримала її у власному будинку. Пізніше, коли для бібліотеки знайшли постійне місце, жінки, а їх була більшість у бібліотечній секції, створили каталоги, розподілили щоденні чергування. Товариство виписувало як періодичні видання, так і мало потужний фонд російської та польської літератури [ДАОО: арк. 45-47]. У Києві польська бібліотека, якою користувалися члени різних польських організацій, належала Е. Д. Олецький [ЦДІАУК (c): арк.6, ЦДІАУК (d): арк. 183, 188.]. В іï будинку проходили також публічні читання, лекції, концерти.

Бібліотеки, що ставали місцем збору польської громадськості різних політичних поглядів, викликали підозру місцевої влади. Жінки, які утримували бібліотеки, ставали об'єктом спостереження жандармерії, а їх квартири - місцем обшуків. У будинку однієї з власниць київської польської бібліотеки К. Д. Чарнецької було влаштовано обшук в жовтні 1912 р. У чотирьохкімнатній квартирі, яку вона орендувала разом із сестрою, дві кімнати були віддані під бібліотеку. Жандарми обшукали всю квартиру і допитали К. Д. Чарнецьку [ЦДІАУК (b): 51]. I хоча подальших обмежень і переслідувань не було, така організаційно-просвітницька 
діяльність, як утримання бібліотеки, була для жінок небезпечною.

Однак не всі польські організації були відкриті для жінок. Фактично закритими залишалися спортивні організації, т. зв. «Польські соколи», а також наукові товариства.

Польські жителі міст Російської імпеpiї на рубежі XIX-початку XX ст. прагнули підтримувати духовну культуру свого народу. Жінки, традиційно зосереджені в приватній сфері сім'ї та дому, брали участь у культурному житті спільноти. Їх досвід громадської діяльності був обмежений благодійністю, що вважалася традиційно жіночою сферою, навіть, призначенням. Однак поступово жінки були залучені і в організа-

\section{ЛІТЕРАТУРА}

Kalendarz Domu Polskiego w Odesie. 1912.

Kraj. Sankt-Peterburg, 1905.

Łukawski Z. Ludność polska w Rosii: 1863-1914. Wrocław, 1978.

Sobanska z Grocholskich, M. Wspominki nikle. Grodzick Mazowiecki, 2002. C. 208.

Весь Петербург на 1910 г. Адресная и справочная книга Санкт-Петербурга.

Горбатовський П. Від аматорського гуртка до професійного театру (польський театр у Києві в 19051914 рр.) // Слов'янський світ: Зб. наук. пр. К.: ІМФЕ ім. М.Т. Рильського НАН України, 2008. Вип. 6. С. 67-92.

Горун Д. О. Польська громада Одеси у XIX - початку Хх ст.: коротка характеристика етапів розвитку // Записки історичного факультету ОНУ. Вип. 13. Одеca, 2003. С. 72-85.

ДАОО (Державний архів Одеської області) Ф. 2. Оп. 7. Спр. 38.

ДАОО (Державний архів Одеської області).

Коженьовській М. За золотимми ворітьми. Суспільно-культурна діяльність поляків у Києві в 1905-1920 роках. К., 2015. 664 с.

Куліш Н. Одеський Дім Польський // Південний архів. Херсон, 2001. № 5. С.124-127.

Ніколаєнко О.Громадська діяльність польських жінок Одеси на початку XX ст. // Чорноморський літопис 2012, № 6. С. 82-89.

Ніколаєнко О. О. Польські жінки Наддніпрянської

\section{REFERENCES}

Kalendarz Domu Polskiego w Odesie. (1912) [A calendar of Polish House is in Odesa] [in Polish].

Kraj. - Sankt-Peterburg 1905[in Polish].

Łukawski Z. Ludność polska w Rosii: 1863-1914. [The Polish society is in Russia] - Wrocław, 1978[in Polish].

Sobanska z Grocholskich, M. Wspominki nikle. Grodzick Mazowiecki, 2002. C. 208 [in Polish]. цію культурного життя польської діаспори.

Розмаїття польських національно-культурних громадських організацій, що виникли після революції 1905-1907 рр., сприяло залученню жінок до участі в театральному, музичному, літературному і художньому житті полонії. Польки виступали організаторами і учасницями концертів, музично-танцювальних вечорів, виконавцями віршів і театральних вистав. Така діяльність надавала досвід участі в громадському житті, дозволяла не тільки проводити вільний час, а й підтримувати національну культуру, протиставляючи іiі асиміляційній політиці держави.

України в другій половині XIX - на початку XX ст.: громадське і приватне життя. Монографія / О. О. Ніколаєнко. Харків, 2015. 360 с.

Первая всеобщая перепись населения Российской империи 1897 г. Т. 16. Киевская губерния; Т. 24. Город Москва. Кн.1-2.; Т. 38. Город Санкт-Петербург; Т. 47. Херсонская губерния. Б. м, 1903 г.

Поляки в России: история и современность. Краснодар, 2007

Поляки в России: эпохи и судьбы. Краснодар, 2009.

Рымарь Н. Н. Польские общества в Одессе конца XIX - начала XX вв./ Н. Н. Римар// Дім князя Гагаріна: зб. іст. публікацій. Вип. 2. Одеса, 2001. С. 107111; Смирнова Т. М. Польские общества СанктПетербурга конец XIX - начало XX вв. СПб, 2013.

ЦДІАУК (а) (Центральний державний історичний архів України в м. Києві). Ф. 274. Оп. 1. Спр. 3099.

ЦДІАУК (b). Ф. 275. Оп. 2. Спр. 95.

ЦДІАУК (c). Ф. 275. Оп.1. Спр. 1934.

ЦДІАУК ( d). Ф. 442. Оп. 857. Спр. 2.

Чаплицкий Б. Католическая благотворительность в России: 1860-1917. СПБ, 2009. С. 126-137.

Чаплицкий Б. Монашеские конгрегации в приходе Посещения Пресвятой Девы-Марии в СанктПетербурге и их судьба в советское время.// Материалы к истории римско-католического прихода во имя Посещения Пресвятой девой Марией св. Елизаветы и к истории католического кладбища выборгской стороны Санкт-Петербурга. СПб, 2010. С. 142-157.

Ves Peterburg na 1910.Adresnaya I spravochnaya kniga Sankt-Peterburga. [All Petersburg on 1910. The Address and certificate book of Saint Petersburg] СПб. [in Russian].

Gorbatovsky P. (2008) Vid amatorskogo gurtka do profesijnogo teatru (polskij teatr u Kyevi v 1905-1914 rr. [From an amateur group to the professional theatre (the Polish theatre is in Kyiv in 1905-1914) ] Slovjanskij svit. 
Zbirnyk naukovyh prac [the Slavic world: Collection of scientific works], issue 6, 67-92 [in Ukranian].

Gorun D. O. (2003) Polska gromada Odesy k. XIX poch. XX st. korotka harakterystyka etapiv rozvytku [Polish society of Odesa in XIX - to beginning of XX of century : short description of the stages of development] Zapysky istorychnogo fakultetu ONU - Messages of historical faculty ONU, Issue 13, 72-85 [in Ukranian].

ДАОО (Державний архів Одеської області - State Archives of Odessa Region). Ф. 2, ОП. 7, Д. 38.

ДАОО (Державний архів Одеської області - State Archives of Odessa Region).

Kozeniowskij M. (2015) Za zolotymi voritmy. Suspilnokulturna diyalnist polyakiv $v$ Kyevi v 1905-1920 rokah [After a golden gate. Publicly-cultural activity of Poland is in Kyiv in 1905-1920]. Kyiv [in Ukranian].

Kulish N. (2001) Odeskij Dim Polskij.[ Odesa House Polish] Pivdennyj arhiv - South arhive, 5, 124-127 [in Ukranian].

Nikolayenko O. (2012) Gromadska diyalnist polskih zinok Odesy na pochatku XX st. [Public activity of the Polish women of Odesa at the beginning XX of century]. Chornomorsyj litopys - The Black Sea chronicle 6, 82-89 [in Ukranian].

Nikolayenko O. (2015) Polski zinky Naddnipryanskoj Ukrainy $v$ drugij polovyni XIX - na pochatku XX st.: gromadskie I pryvatne zyttya [Polish women of Ukraine in the second half of XIX - at the beginning XX of century : public and private life] [in Ukranian].

Pervaya vseobshchaya perepis naseleniya Rosijskoj imperii 1897 g. [ First universal census of population of the Russian empire of a 1897] Kievskaja guberniya. [Kyiv province; T. 24. City Moscow. KH.1-2.; T. 38. City Saint Petersburg; T. 47. it is the Kherson province.] [in Russian].
Polaki v Rossii: istoriya I sovremennost. (2007)[ Poles in Russia: history and modernity] [in Russian].

Polaki v Rossii: epohi I sudby (2009) [Poles in Russia: eras and destinies] [in Russian].

Rymar N. (2001) Polskie obshchestva v Odese konca XIX-nachala XX vv. [Polish societies are in Odesa of end of XIX - XX вв began]. Dim kniaza Gagarina: zb. Ist.publikacij [House of prince Gagarin : Collection of historical publications], Issue 2, 107-111] [in Russian].

Smirnova T. M. (2013) Polskie obshchestva SanktPeterburga konec XIX-nachalo XX vv. [Polish societies of St. Petersburg late 19th - early 20th centuries]. СПб, 2013] [in Russian].

ЦДІАУК (Центральний державний історичний архів України в м. Києві - Central state historical archive of Ukraine in Kyjv) (a). Ф. 274, Оп. 1, Спр. 3099.

ЦДІАУК (b). Ф. 275, Оп. 2, Спр. 95.

ЦДІАУК (c). Ф. 275, Оп.1, Спр. 1934.

ЦДІАУК (d). Ф. 442, Оп. 857, Спр. 2.

Czaplickyj В. (2009) Katoliczeskaya blagotvoritelnost $v$ Rosii: 1860-1917 [Catholic charity is in Russia: 18601917.] SPb. [in Russian].

Czaplickyj B. (2010) Monasheskie kongregacii v prihodie Poseshcheniya Presvyatoj devy Marii v SanktPeterburgie I ich sudba v sovetskoye vremia [Monastic groups in arrival of Visit of the most Holy Virgo-Maria in Saint Petersburg and their fate in soviet time] Materialy $k$ istorii rimsko-katolicheskogo prihoda vo imia Poseshcheniya Presvyatoj Devoj Mariej sv. Elizavety $I k$ istorii katolicheskogo kladbishcha vyborgskoj storony Sankt-Peterburga [Materials to history of catholic arrival in the name Visit by the most Holy virgin by Maria skt. Elisabeth and to history of catholic cemetery of the Vyborg side of Saint Petersburg] [in Russian].

Мараховська Е. В. кандидат філософських наук, дочент, К3 «Харківська гуманітарно-педагогічна академія» Харківської обласної ради, м. Харків

\section{КУЛЬТУРА ПОВСЯКДЕННОСТІ ІНТЕЛІГЕНЦЇ̈ ПІЗНЬОРАДЯНСЬКОЇ ДОБИ ЯК РЕПРЕЗЕНТАЦІЯ КРИЗИ СИСТЕМНИХ ЦННОСТЕЙ}

У статті розглянуто особливості культури повсякденності й необхідність ї̈ вивчення для формування повної картини розвитку культури певного історичного періоду, значення повсякденності в житті людини. Виявлено ціннісні домінанти культури пізньорадянського періоду, ставлення широких кіл украӥнської інтелігенції до ідеологічних засад радянської культури. Визначено, що повсякденне життя інтелігенції репрезентувало кризу радянських иінностей, широкі кола науково-технічної $i$ педагогічної інтелігенції, навіть незважаючи на певну аполітичність, були налаштовані опозиційно до радянської системи, що виявлялося через читащькі, глядаџькі, музичні, побутово-речові уподобання.

Ключові слова: пізньорадянська доба, інтелігенція, иінності, ідеологія, повсякденність, побут.

The aim of the article is to identify the peculiarities of worldview and life values of broad circles of the Ukrainian intelligentsia of the late Soviet era.The peculiarities of the culture of everyday life and the need to 